\title{
ZORGANIZOWANE FORMY AKTYWNOŚCI RELIGIJNEJ I SPOLECZNEJ POLSKICH EMIGRANTÓW PRZY PARAFII PW. ŚWIĘTEJ TRÓJCY W CHICAGO W LATACH DWUDZIESTYCH I TRZYDZIESTYCH XX WIEKU
}

Kościół pw. Świętej Trójcy w Chicago zbudowali w 1873 roku polscy emigranci zrzeszeni w Towarzystwie św. Józefa ${ }^{1}$. Przez pierwszych dwadzieścia lat kościół ten, funkcjonujący jako filia parafii św. Stanisława Kostki ${ }^{2}$ prowadzonej przez księży zmartwychwstańców ${ }^{3}$, był trzykrotnie zamykany przez władze archidiecezji (w latach 1876, 1881, 1889). Powodem było dążenie „trójcowian” do ustanowienia odrębnej jednostki, co powodowało konflikt z księżmi zmartwychwstańcami ${ }^{4}$. W 1893 roku oficjalnie została utworzona parafia pw. Świętej Trójcy,

Mgr Genowefa Potaczala MChR - Centralne Archiwum Polonii Amerykańskiej w Orchard Lake; e-mail: gpotaczala@yahoo.com

${ }^{1}$ Dzieje Parafii Świętej Trójcy 1873-1898. Na pamiątkę 25-letniego jubileuszu założenia parafii św. Trójcy (1898), oprac. A. Małłek i in., Chicago, [1898], s. 7.

${ }^{2}$ Parafia św. Stanisława Kostki - pierwsza polska parafia na terenie Chicago utworzona w 1869 roku staraniem Towarzystwa Dobroczynnego św. Stanisława Kostki (St. Stanislaus Kostka Benevolent Society, założona 1867), pod duszpasterską opieką księży zmartwychwstańców. Złoty jubileusz Najstarszej Polskiej Parafii Świętego Stanisława Kostki w Chicago, 1867-1917, Chicago.

${ }^{3}$ Zgromadzenie Zmartwychwstania Pana Naszego Jezusa Chrystusa - wspólnota zakonna założona w 1836 roku w Paryżu, dla podtrzymania ducha katolickiego w rozporoszonym na emigracji narodzie polskim. Aktywną działalnością zmartwychwstańcy odznaczyli się przede wszystkim w Stanach Zjednoczonych, gdzie oprócz posługi duszpasterskiej, zajmowali się działalnością charytatywną, oświatową, kulturową. Przyczynili się do założenia wielu parafii na terenie Chicago. Do najwybitniejszych przedstawicieli zgromadzenia należeli: Wincenty Barzyński (współzałożyciel Zjednoczenia Polskiego Rzymsko-Katolickiego), Adolf Bakanowski (proboszcz parafii św. Stanisława Kostki w Chicago), Feliks Zwiardowski. J. IwICKI, The First One Hundred Years. A study of the Apostolate of the Congregation of the Resurrection in the United States 1866-1966, Rome 1966, s. 9-14.

${ }^{4}$ Konflikt w początkowej fazie istnienia kościoła Świętej Trójcy w Chicago opisany w: Dzieje Parafii Świętej Trójcy 1873-1898. 
opiekę nad nią powierzono polskim księżom ze Zgromadzenia Krzyża Świętego (CSC). Największy rozkwit Trójcowa przypadł na pierwszą połowę XX wieku, co pokrywa się z czasem kadencji pierwszego proboszcza, ks. Kazimierza Sztuczki CSC (1893-1949)5 . W latach 20. i 30. do parafii należało ponad 15 tys. wiernych, szkoła podstawowa (istniejąca od $1877 \mathrm{roku}^{6}$ ) osiągnęła apogeum w 1923 roku 3183 uczniów $^{7}$, szkoła średnia dla chłopców - Holy Trinity High School (założona w 1910 roku $^{8}$ ) w latach 30. liczyła blisko 300 uczniów $^{9}$.

Wokół dwóch pierwszych polskich kościołów w Chicago w krótkim czasie wyrosła polska dzielnica (Polish Downtown), a w miarę jej rozrastania budowano kolejne świątynie ${ }^{10}$. Cechą charakterystyczną skupisk Polaków było tworzenie rozbudowanych infrastruktur parafialnych, które stanowily podstawowe i najważniejsze centra ich życia duchowego i społecznego ${ }^{11}$. Znajdowało to odzwierciedlenie w licznych formach aktywności: organizacjach, chórach, towarzystwach, uroczystościach itp. podejmowanych przez wiernych.

W latach 20. i 30. XX wieku w parafii Świętej Trójcy działało ponad pięćdziesiąt bractw i towarzystw. Skupiały one parafian w odpowiednich grupach wiekowych i stanowych, np. mężczyzn, kobiety, młode matki ${ }^{12}$, dzieci i młodzież. Wiele z towarzystw było przede wszystkim organizacjami bratniej pomocy i przynależało do naczelnych instytucji polonijnych, głównie do Związku Narodowego Polskiego $^{13}$. Zasady funkcjonowania poszczególnych organizacji były podobne. Niemal w każdym towarzystwie obowiązywały comiesięczne składki członkowskie, partycypowały one również we wszelkich wydatkach finansowych parafii, fundując np.

5 Pamiątka złotego jubileuszu kapłaństwa wielebnego księdza Kazimierza S. Sztuczki C.S.C. [...], Chicago [1941].

${ }^{6}$ Pamiętnik parafii Świętej Trójcy w Chicago (1893-1918). Z okazji 25 rocznicy otwarcia kościoła przez J.E. Ks. Kard. F. Satolliego, delegata papieskiego, Chicago [1918], s. 83.

${ }^{7}$ Pamiatka złotego jubileuszu kapłaństwa wielebnego ks. Kazimierza S. Sztuczki C.S.C., s. 62.

8 „Odgłos Trójcowa” 2(1910), nr 7, s. 2.

9 Pamiętnik z okazji czterdziestolecia otwarcia kościoła w Parafii Św. Trójcy, czerwiec 1933, Chicago, Illinois, 1933, s. 39.

10 E.R. Kantowicz, Polish-American Politics in Chicago, 1888-1940, Chicago 1975, s. 14-17.

${ }^{11}$ B. Leś, Kościót w procesie asymilacji Polonii amerykańskiej: przemiany funkcji polonijnych instytucji i organizacji religijnych w środowisku Polonii chicagowskiej, Wrocław 1981, s. 33.

12 „Odgłos Trójcowa” 12(1920), nr 5, s. 32-34.

13 Związek Narodowy Polski (Polish National Alliance) - założony w 1880 roku w Filadelfii, jako jedna z pierwszych i najbardziej wpływowych organizacji polonijnych w Stanach Zjednoczonych, mająca na celu finansowe wspieranie polskich emigrantów oraz pielęgnowanie ich świadomości narodowej, z czasem zyskała znaczenie polityczne. ZNP wydawał czasopisma „Zgoda” (od 1880 roku, tygodnik) oraz „Dziennik Związkowy” (od 1908 roku). E.R. Kantowicz, Polish-American Politics, s. 10, 35-36. 
figury świętych zdobiące wnętrze kościoła czy sprzęt liturgiczny ${ }^{14}$. Za korzystanie z sal parafialnych towarzystwa uiszczały parafii konkretne opłaty. Przynależność do bractw i towarzystw dawała pewne przywileje duchowe ich członkom: modlitwę za zmarłych członków, udział w pogrzebie, zamawianie mszy św. w intencji tychże zmarłych. Wszelkie uroczystości kościelne odbywały się z udziałem bractw i towarzystw parafialnych, zachowujących ceremonie procesyjnego wchodzenia na uroczystości. Praktykowano też tzw. wspólne komunie św., gdzie wszyscy członkowie danego bractwa przystępowali gremialnie do sakramentu Eucharystii poprzedzonej spowiedzią. Najbardziej dynamicznie działające towarzystwa organizowały występy, koncerty, akademie, wieczorki, majówki, bale, zabawy ${ }^{15}$.

Dla koordynacji działań poszczególnych towarzystw powołano w 1903 roku naczelną organizację pod nazwą Osada Świętej Trójcy, która wchodziła jednocześnie w skład Federacji Polaków Katolików w Ameryce ${ }^{16}$. Według danych z 1920 roku, 43 towarzystwa wchodziły w skład federacji, a 13 pozostawało niezrzeszonych ${ }^{17}$. W 1929 roku naczelną organizację nazwano Połączone Towarzystwa Parafii Świętej Trójcy $^{18}$. W jej skład wchodzili reprezentanci poszczególnych grup parafialnych. $\mathrm{Na}$ corocznym posiedzeniu prezentowano działalność wszystkich stowarzyszeń, składano sprawozdania i wybierano pięcioosobowy zarząd, który co miesiąc odbywał posiedzenia. Omawiano wówczas sprawy parafialne, będące przedmiotem wspólnej troski Połączonych Towarzystw: organizowanie pikników, bazaru, wycieczek parafialnych, obchodów świąt narodowych, organizowania składek na cele dobroczynne ${ }^{19}$.

\section{ZEBRANIA TOWARZYSTW}

Poszczególne organizacje parafialne każdego roku odbywały posiedzenia walne, na których dokonywano bilansu działalności i wybierano nowy zarząd, który składał przysięgę na ręce proboszcza. Na tego rodzaju posiedzeniach wytyczano plan działań towarzystwa na najbliższy rok, zarówno w sferze materialnej, jak i duchowej. Roczne posiedzenie zazwyczaj odbywało się przy kolacji, były to tzw. wieczory instalacyjne, które miały swój program artystyczny, składający się z prze-

14 „Odgłos Trójcowa” 12(1920), nr 4, s. 26.

15 „Odgłos Trójcowa” 21(1929), nr 1, s. 4-8.

16 „Odgłos Trójcowa” 1(1990), nr 2, s. 7.

17 „Odgłos Trójcowa” 12 (1920), nr 2, s. 18.

18 „Odgłos Trójcowa” 22(1930), nr 1 s. 8.

19 G. Potaczala, Polacy na Trójcowie. Dzieje kościoła pw. Świętej Trójcy w Chicago, Poznań 2007, s. 148. 
mówień, odczytów, deklamacji, występów muzycznych, a nierzadko wystawiano przedstawienie teatralne. Jako ilustracja posłużyć może wieczorek instalacyjny Towarzystwa Imienia Jezus, który odbył się w środę 8 stycznia 1928 roku. Program rozpoczęto śpiewem w wykonaniu czterech panien przy akompaniamencie fortepianu i skrzypiec, mowę okolicznościową wygłosił były alderman (ławnik miejski), po nim przemówił proboszcz, następnie śpiewano solo i recytowano wiersz „Święty Jan Kanty”. Kolejnym punktem programu był humorystyczny monolog, na zakończenie przedstawiono farsę „To polityka” ${ }^{20}$. Oprócz spotkań rocznych, każda organizacja odbywała comiesięczne posiedzenie, z którego spisywano protokół. Plan posiedzeń dla poszczególnych towarzystw został rozłożony na cały miesiąc i podawany był $w$ parafialnym biuletynie ${ }^{21}$.

\section{WIECZOREK KOMITETÓW PARAFIALNYCH}

Każdego roku w ostatnich dniach grudnia organizowano bankiet dla wszystkich zespołów, tzw. wieczorek komitetów parafialnych, podczas którego odbywała się też część artystyczna z deklamacjami, śpiewami, przemówieniami i oprawą muzyczną, czasami organizowano zbiórkę na cele charytatywne. W 1925 roku wieczorek komitetów parafialnych odbył się w niedzielę, w kafeterii szkolnej. Obecnych było około 200 osób, reprezentujących różne organizacje i komitety. Po kolacji zabierali głos przedstawiciele poszczególnych towarzystw i księża, mowy były przeplatane śpiewami chóru kościelnego, deklamacjami i muzyką orkiestry E. Nowakowskiego. Na zakończenie chór Arcybractwa Niepokalanego Serca Maryi zaśpiewał pieśń „Dobranoc”. Obiad przygotowały członkinie Towarzystwa św. Wincentego a Paulo, do stołu podawały członkinie Arcybractwa Niepokalanego Serca Maryi ${ }^{22}$.

\section{ZEBRANIE ROCZNE}

W pierwszą niedzielę nowego roku odbywało się zebranie całej społeczności parafialnej, na którym dokonywano podsumowania minionego roku i wytyczano cele na rok następny. Zebranie organizowano w audytorium szkoły, prawo wstępu i zarazem prawo głosu mieli wyłącznie parafianie opłacający przynajmniej jedno miejsce siedzące w kościele. Na podium zasiadał proboszcz i aktualni urzędnicy

\footnotetext{
20 „Odgłos Trójcowa” 20(1928), nr 2, s. 26.

${ }^{21}$ Tamże, s. 56.

22 „Odgłos Trójcowa” 17(1925), nr 1, s. 22-24.
} 
parafii: członkowie Komitetu Kościelnego, członkowie Wydziału Szkolnego i reprezentanci towarzystw parafialnych. Po modlitwie prowadzonej przez proboszcza odczytywany był protokołów z poprzedniego zebrania, a po jego zatwierdzeniu proboszcz czytał sprawozdanie ze stanu ogólnego parafii, stan finansowy przedstawiał kasjer parafii, następnie prezentowano sprawozdania z działalności szkół parafialnych, towarzystw i z działalności charytatywnej ${ }^{23}$. W latach 30 . doszły sprawozdania z Akcji Katolickiej. Po sprawozdaniach dyskutowano nad nowymi uchwałami i na koniec dokonywano wyboru nowych urzędników na następny rok, czyli sekretarza, kasjera, marszałka zewnętrznego i marszałka wewnętrznego oraz funkcyjnych do różnych komitetów parafialnych ${ }^{24}$.

\section{IMIENINY PROBOSZCZA}

Dzień 4 marca - wspomnienie św. Kazimierza królewicza, był świętem całej wspólnoty obchodzonym bardzo uroczyście. Na imieniny proboszcza Kazimierza Sztuczki dzieci szkolne przygotowywały specjalny program artystyczny, który prezentowały w niedzielę po południu. W roku 1925 na program złożyły się występy dziewcząt i chłopców z klas ósmych, mianowicie śpiew przy akompaniamencie szkolnej orkiestry, gimnastyka i musztra chłopców w mundurach policyjnych i strojach rzymskich. Przedstawiono też dramat religijny „Ostatnie dni Najświętszej Maryi Panny”, a także komedię „Uncle Jacob’s Statue”25. W ciągu tygodnia towarzystwa parafialne urządzały tzw. wieczorek, podczas którego delegacje z kilkudziesięciu towarzystw oraz ze szkoły średniej składały proboszczowi życzenia. Wieczorki miały również swoją oprawę artystyczną. Rozpoczynały się od wprowadzenia przez skautów flagi polskiej i amerykańskiej, mową wstępną, następnie modlono się i delegacje kilkudziesięciu towarzystw składały życzenia, po czym odbył się program artystyczny. W 1936 roku na wieczorku zaprezentowano: śpiew chórów parafialnych, muzykę na akordeonie, śpiewy solo, deklamacje, taniec krakowiak w wykonaniu Sodalicji św. Teresy, na koniec Kółko Literackie zagrało jednoaktową komedię „O Józię”. Trzecim etapem świętowania imienin proboszcza był bankiet, organizowany w kolejną niedzielę. Tradycyjnie organizatorami byli: Klub Obywatelski im. Kazimierza Pułaskiego oraz Klub Obywatelek Trójcowa. Bankiet odbywał się zwykle w kafeterii szkolnej i gromadziło się na nim około 600 osób. Oto opis bankietu z 1937 roku: solenizanta wprowadzano do

\footnotetext{
23 „Odgłos Trójcowa” 24(1932), nr 2, s. 2-4.

24 „Odgłos Trójcowa” 12(1920), nr 1, s. 6.

25 „Odgłos Trójcowa” 17(1925), nr 5, s. 52.
} 
sali wśród oklasków i muzyki w wykonaniu orkiestry szkolnej. Modlitwę odmówił ks. J. Szymanowski, przemówienie powitalne wygłosił jeden z założycieli „Trójcowa", W. Sajewski, który na mistrza toastów powołał aldermana F. Konkowskiego. Po kolacji przemówienia wygłosili kolejno: prof. S. Gałązka w zastępstwie nieobecnego w mieście konsula dr. W. Gawrońskiego, ks. S. Kuszyński, W. Wieczorek - prezes Wydziału Szkolnego w parafii pw. Świętej Trójcy, A. Milasiewicz - wiceprezeska Związku Polek w Ameryce, J. Romaszkiewicz ze Związku Narodowego Polskiego, S. Adamkiewicz - dyrektor Zjednoczenia Polskiego Rzymsko-Katolickiego ${ }^{26}$. Na program artystyczny złożyły się: śpiew solowy przy akompaniamencie fortepianu, utwory w wykonaniu orkiestry szkolnej, taniec indiański skautów. Następnie krótkie przemówienia wygłosili: br. Wiktor - dyrektor szkoły średniej, T. Białoruska - prezeska Klubu Obywatelek Trójcowa, T. Mróz - prezes Stowarzyszenia Polskich Tawernistów, K. Juszczyk z Cleveland (Ohio). Po podziękowaniu przez proboszcza wszystkim zebranym za zorganizowanie uroczystości, wspólnie zaśpiewano „Boże coś Polskę”27.

\section{PIKNIK}

Każdego roku w lipcu odbywał się piknik, zwany wycieczką parafialną, na który cała społeczność parafii wyjeżdżała na podmiejskie tereny parkowe. Piknik organizowany był przez Klub Obywatelski im. Kazimierza Pułaskiego oraz Klub Obywatelek Trójcowa. Czasami partycypowały w przygotowaniach inne towarzystwa. Do wykonania przedsięwzięcia kilka tygodni wcześniej wybierano komitet organizacyjny. Najczęstszym miejscem piknikowym był park Kloze’s Grove, położony przy ulicy Irving Park w pobliżu skrzyżowania z ulicą Milwaukee. Piknik trwał zwykle do późnych godzin wieczornych. Rozpoczynał się wspólnym wejściem organizujących go towarzystw przy akompaniamencie orkiestry dętej. $\mathrm{Na}$ placu porozstawiane zostały stoiska $\mathrm{z}$ napojami (w tym dozwolone piwo), lodami i słodyczami. Popularne były stoiska loterii, zwane „kołami szczęścia”, gdzie można było wygrać drobne nagrody. O godzinie trzeciej rozpoczynały się

\footnotetext{
${ }^{26}$ Zjednoczenie Polskie Rzymsko-Katolickie - najstarsza organizacja polonijna w Stanach Zjednoczonych, założona w Detroit w 1874 roku, z inicjatywy m.in. ks. L. Moczygęby, ks. T. Gieryka, ks. W. Barzyńskiego, kierowana przez księży zmartwychwstańców. Jej celem było promowanie polskości wśród emigrantów oraz prowadzenie działalności charytatywnej. Wydawało czasopisma, m.in.: „Wiara i Ojczyzna” (1887-1899, tygodnik), „Dziennik Chicagowski” (1890-1971), „Naród Polski” (od 1897 roku, tygodnik). K. DopIERAŁA, Zjednoczenie Polskie Rzymsko-Katolickie w Ameryce, w: Encyklopedia polskiej emigracji i Polonii, red. K. Dopierała, t. V, Toruń 2003, s. 429.

27 „Odgłos Trójcowa” 29(1937), nr 4, s. 12.
} 
zawody. Największą popularnością cieszyły się wyścigi podzielone na kategorie wieku i płci. Po zakończeniu zawodów wydawano uczestnikom obiad, a po nim w głównym pawilonie rozpoczynała się zabawa taneczna, która trwała do późnych godzin wieczornych. Każde stoisko obsługiwały wyznaczone osoby, dbano też o porządek i przyjmowanie gości, ponieważ piknik odwiedzali czasami znaczni mieszkańcy Chicago. Bilety na imprezę rozsyłano do parafian kilka miesięcy wcześniej, ale można było również nabyć bezpośrednio przy wejściu do ogrodu w cenie 65 centów od osoby. Gdy pogoda dopisała, piknik gromadził około cztery tysiące osób ${ }^{28}$.

\section{BAZAR}

Tradycją parafii były też jesienne bazary, urządzane w celu gromadzenia funduszy na potrzeby parafii i na działalność charytatywną. Odbywały się zazwyczaj w październiku w audytorium szkoły podstawowej, obejmowały 10 wieczorów rozciągniętych $\mathrm{w}$ ciągu trzech tygodni. Organizatorami byli Komitet Kościelny oraz Komitet Połączonych Towarzystw. Podobnie jak przy organizacji pikniku, wybierano komitet bazarowy, który koordynował przedsięwzięcie. Do wszystkich parafian rozsyłano bilety na loterię pieniężną, którą losowano podczas ostatniego wieczoru bazarowego. Trębacze ze znanych kapeli Nowakowskiego i Olejniczaka ogłaszali bazar jeżdżąc samochodami po okolicy. Formalne otwarcie bazaru zaczynało się od modlitwy prowadzonej przez ks. proboszcza, przedstawienia komitetu bazaru i przemówienia prezesa komitetu. Chór i orkiestra wykonały kilka pieśni narodowych. Poszczególnym towarzystwom przydzielono różne funkcje. Sprzedawaniem biletów zajmowały się zazwyczaj panie z towarzystwa różańcowego, odbieraniem biletów marszałkowie kościelni, w restauracji bazarowej gości podejmowały panie z Klubu Obywatelek Trójcowa, w bufecie obsługiwali panowie z Klubu Kazimierza Pułaskiego, cygaro sprzedawali młodzieńcy z Towarzystwa Dorastającej Młodzieży, stoiska z kwiatami obsługiwały chórzystki z Towarzystwa Panien Wanda i Towarzystwa Królowej Jadwigi, słodycze i lody sprzedawały panny z Towarzystwa Imienia Maryi, przy dużej loterii asystowały reprezentantki ze Związku Polek, przy tzw. Kotach młodzieńcy z Towarzystwa Młodzieży św. Kazimierza i panny z Towarzystwa Imienia Maryi, przy stoiskach z kocami i kołdrami panny z Arcybractwa Niepokalanego Serca Maryi i Towarzystwa św. Tereni. Przy strzelnicy mężczyźni z Towarzystwa Imienia Jezus i Towarzystwa Serca Jezusa, a przy „stawie z rybkami” Towarzystwo Dzieci Maryi, uczennice

28 Tamże, nr 8, s. 6; 20(1928), nr 8, s. 14. 
ze szkoły podstawowej sprzedawały na stoisku robótki ręczne. Wyznaczono też osoby do dbania o porządek i przyjmowanie gości. Na konto bazaru wolontariusze kwestowali w okolicznych sklepach i firmach, zbierając datki i przedmioty wartościowe. Każdy wieczór adresowano do konkretnej grupy parafialnej lub instytucji, i tak odbywały się: wieczór ojców i matek, wieczór uczniów i uczennic klasy ósmej, wieczór kontraktorów budujących szkołę, wieczór młodzieży, wieczór absolwentów szkoły średniej, wieczór Związku Narodowego Polskiego, wieczór Zjednoczenia Polskiego Rzymsko-Katolickiego, wieczór Obywatelek Trójcowa, wieczór kupców i przemysłowców i inne. Każdego wieczoru do tańca grała orkiestra Nowakowskiego lub Olejniczka, gości zabawiał też klaun i cyganki przepowiadające przyszłość. Odbywały się też inne zabawy, jak pajac w beczce, koniki i bingo. W ostatni dzień bazaru losowano główne nagrody, np. motocykl lub nagrody pieniężne. Poszczególne towarzystwa parafialne były zachęcane do wspólnego uczestnictwa w bazarze. Decyzję o uczestnictwie in corpore podejmowały towarzystwa na miesięcznym posiedzeniu, $\mathrm{w}$ dniu ustalonym zbierali się członkowie danego towarzystwa na podwórzu parafialnym i w uporządkowanych szeregach wchodzili razem do kafeterii, gdzie odbywał się bazar ${ }^{29}$.

\section{WIELKI POST}

Trójcowianie nie tylko urządzali wspólne zabawy, ale też modlitwa miała formy wspólnotowe. Towarzystwa parafialne praktykowały bowiem wspólne przystępowanie do spowiedzi i komunii św. i wspólnie brały udział w różnych uroczystościach kościelnych. Podczas Wielkiego Postu wyznaczano dni spowiedzi i komunii św. dla poszczególnych towarzystw. W każdą sobotę Wielkiego Postu wyznaczone towarzystwa przystępowały do spowiedzi, a następnego dnia do komunii św. podczas mszy św. o godz. 7:30. Dwa czwartki Wielkiego Postu rezerwowano na spowiedź dzieci szkolnych (klasy starsze i młodsze), komunii udzielano im następnego dnia o 7:45. Ostatnie towarzystwa przystępowały do spowiedzi po Wielkanocy w sobotę przed niedzielą Świętej Trójcy, kiedy to zgodnie z Katechizmem Kościoła Katolickiego kończy się czas obowiązkowej dorocznej spowiedzi wielkanocnej ${ }^{30}$.

29 „Odgłos Trójcowa” 12(1920), nr 1, s. 26; 20(1928), nr 11, s. 30; „Dziennik Związkowy” 15 X 1929; 17 X 1931.

30 „Odgłos Trójcowa” 12(1920), nr 3, s. 12. 


\section{WIELKANOC}

Uroczysta procesja rezurekcyjna rozpoczynała się o godz. 5. Brali w niej udział skauci Świętej Trójcy, II Oddział Wolnych Polskich Krakusów w mundurach oraz panie z Towarzystwa Strzelców Obrony Białego Orła w uniformach. Za nimi w procesji szli ministranci, chłopcy z liliami i dziewczynki sypiące kwiaty. Podczas procesji Strzelcy Obrony Orła Białego zgromadzeni na podwórzu szkolnym oddawali salwy z muszkietów na wiwat dla Zmartwychwstałego ${ }^{31}$. Chóry kościelne przygotowywały się bardzo starannie do największych świąt chrześcijaństwa. W górnym kościele o godz. 5 chóry panien Wanda i mężczyzn śpiewały „Mszę” L. Perosiego, na następnej mszy św. chór dziewcząt z klas ósmych śpiewał „Mszę De Angelis”, natomiast chór Królowej Jadwigi - „Mszę” na cześć św. Piotra, a podczas sumy chórzyści śpiewali „Mszę” Józefa Ksawerego Poniatowskiego. W dolnym kościele mszy św. towarzyszył chór Arcybractwa Niepokalanego Serca Maryi i chóry szkolne ${ }^{32}$.

\section{ODPUST PARAFIALNY}

W omawianych latach, w Niedzielę Trójcy Świętej klasy ósme przystępowały do uroczystej komunii i bierzmowania. Do Pierwszej Komunii św. przystępowały dzieci w młodszych klasach szkoły podstawowej zwykle w dniu Wniebowstąpienia Pańskiego, odbywało się to bez specjalnej zewnętrznej oprawy. Natomiast do tzw. uroczystej Komunii św. przystępowały dzieci w klasie ósmej, ubrane w uroczyste stroje. Tego samego dnia biskup udzielał im sakramentu bierzmowania. Oto jak wyglądał dzień odpustu w 1937 roku: ceremonie rozpoczęły się około godz. 7 procesyjnym wymarszem dzieci klas ósmych. Pochód prowadziła orkiestra E. Nowakowskiego. Za nimi szli marszałkowie kościelni, ministranci, duchowieństwo, członkowie wydziału szkolnego, mali chłopcy i dziewczęta jako asysta i wreszcie sami kandydaci, którzy przystąpili do uroczystej Komunii św. podczas mszy św. o godz. 7:30. Po południu o godz. 14 przyjmowano młodzież do szkaplerza i do towarzystw. Chłopców przydzielono do Towarzystwa Dzieciątka Jezus, a dziewczęta do Towarzystwa Dzieci Maryi. Bierzmowanie, do którego przystąpiło 261 osób, odbyło się o godz. 19:30, sakramentu udzielił bp W. O’Brien, który uroczystość zakończył przemówieniem w języku polskim ${ }^{33}$.

\footnotetext{
31 „Odgłos Trójcowa” 27(1935), nr 5, s. 2.

32 „Odgłos Trójcowa” 18(1926), nr 3, s. 48.

33 „Odgłos Trójcowa” 29(1937), nr 6, s. 2.
} 


\section{ADWENT - CZTERDZIESTOGODZINNE NABOŻEŃSTWO}

W pierwszym tygodniu Adwentu odbywało się 40-godzinne nabożeństwo, rozpoczynało się we wtorek, a kończyło w czwartek. W 1929 roku, 3 grudnia, rozpoczęło się o godz. 9 uroczystą sumą z kazaniem i procesją, we środę i czwartek sumę odprawiano o godz. 10. Natomiast o godz. 19:30 każdego dnia odbywały się nieszpory, szczególnie uroczyste z kazaniem i procesją w czwartek na zakończenie nabożeństwa. W adoracji Najświętszego Sakramentu brały udział towarzystwa: Apostolstwo Modlitwy, Towarzystwo Adoracji Najświętszego Sakramentu, Niewiast Różańcowych, Dzieci Maryi, Dziewic Różańcowych i Arcybractwo Niepokalanego Serca Maryi. Na spowiedź wyznaczone były godziny popołudniowe i wieczorne. Towarzystwa żeńskie przystępowały do spowiedzi we wtorek, a męskie w środę. Spowiedź dzieci szkolnych odbyła się w piątek i poniedziałek, dni poprzedzające czterdziestogodzinne nabożeństwo. Przy udzielaniu komunii każdy otrzymywał obrazek, który wręczano dzieciom szkolnym. Dziecko, które przyniosło najwięcej obrazków, otrzymywało książeczkę do nabożeństwa, a klasa, która zebrała najwięcej obrazków, otrzymywała figurę Serca Pana Jezusa ${ }^{34}$.

\section{BOŻE NARODZENIE}

Podobnie jak na Wielkanoc, chóry parafialne przygotowywały muzyczną oprawę mszy św. Chór męski i chór mieszany wykonywali kolędy na cztery głosy przy akompaniamencie orkiestry symfonicznej szkoły średniej. W 1922 roku chóry zaśpiewały podczas pasterki mszę łacińską, skomponowaną w stylu polifonicznym na tematy kolęd polskich ${ }^{35}$.

\section{INNE NABOŻEŃSTWA}

Podobnie obchodzono święto patronalne niektórych towarzystw, podczas którego dane towarzystwo uczestniczyło w nowennie poprzedzającej święto patrona, w wigilię święta przystępowało do spowiedzi. W dniu święta członkowie towarzystwa, z przypiętymi odznakami towarzystwa, gromadzili się na placu kościelnym ze sztandarem i procesyjnie wchodzili do kościoła na mszę św., podczas której przystępowali razem do komunii. Zwykle po południu towarzystwo brało udział w nieszporach i odbywało

\footnotetext{
34 „Odgłos Trójcowa” 15(1923), nr 12, s. 10.

35 Tamże, nr 1, s. 34
} 
swoje posiedzenie, na którym przyjmowano nowych adeptów. Towarzystwo św. Józefa obchodziło dzień patronalny 19 marca, Towarzystwo św. Antoniego - 13 czerwca, Towarzystwo Matki Boskiej Szkaplerznej - 16 lipca, Towarzystwo św. Anny 26 lipca, Towarzystwo św. Tereni - 1 października, Arcybractwo Niepokalanego Serca Maryi - 8 grudnia. Towarzystwa maryjne celebrowały uroczystość Wniebowzięcia NMP, a także brały udział w nabożeństwach majowych i październikowych. W czerwcowych nabożeństwach uczestniczyło Towarzystwo Najświętszego Serca Jezusa i Apostolstwo Modlitwy. Oprócz wymienionych świąt, wiele innych towarzystw zamawiało intencje mszy św. za zmarłych członków i wspólnie przystępowało do spowiedzi i komunii św.

\section{MISJE PARAFIALNE}

Co pięć lat w parafii odbywały się dwutygodniowe misje parafialne. W 1933 roku nauka wstępna odbyła się w sobotę 11 listopada. W pierwszym tygodniu głoszone były nauki dla panien i mężatek, wtedy też księża słuchali spowiedzi. W niedzielę żeńska społeczność przystępowała do komunii św. W drugim tygodniu misji taki sam plan przewidziano dla mężczyzn i młodzieńców. Na znak przeprowadzonych misji poświęcono krzyż misyjny. Podczas trwania misji nie organizowano żadnych zabaw parafialnych ${ }^{36}$.

\section{OBCHODY NARODOWE}

Od początku istnienia parafii, a nawet przed jej utworzeniem, przywiązywano dużą wagę do obchodów rocznic narodowych, były to tzw. obchody styczniowe, obchody majowe i obchody listopadowe. W styczniu oddawano hołd powstańcom styczniowym, w latach 20. obchody organizował komitet kościelny parafii, w latach 30. Akcja Katolicka. Uroczystości w 1920 roku rozpoczęła orkiestra szkolna, wykonując hymny narodowe - amerykański i polski, potem skauci złożyli hołd sztandarom, następnie wygłoszono słowo wstępne i inwokację, główną mowę wygłosił adwokat H. Dankowski, zachęcając do zachowania polskości i przestrzegając przed niebezpieczeństwem komunizmu. Wykonano utwory muzyczne: duet na skrzypcach i akordeonie, a także na klarnecie i fortepianie, były też śpiewy solo przy akompaniamencie fortepianu. Chór św. Tereni zaśpiewał pieśni „Patrz

\footnotetext{
36 „Odgłos Trójcowa” 25(1933), nr 12, s. 2.
} 
Kościuszko”, „Za górą słonko”, orkiestra szkolna zagrała polkę „Cieszmy się”. $\mathrm{Na}$ koniec skauci wystawili scenkę „Olbrzym i karzeł”, a Kółko Dramatyczne jednoaktówkę „Brzytwa swatem”. Nie zabrakło wspólnego śpiewu „Boże coś Polskę"37.

\section{OBCHODY MAJOWE}

Obchody majowe, czyli święto Konstytucji 3 maja, organizował Związek Narodowy Polski przy współpracy miejscowych towarzystw parafialnych i dzieci szkolnych. W latach 30. obchody w parafii organizowała Akcja Katolicka. Oto przykład programu obchodu tzw. wiecu narodowego z 1937 roku, który odbył się w poniedziałek 3 maja wieczorem. Rozpoczynano, podobnie jak podczas wielu uroczystości, wprowadzeniem flagi polskiej i amerykańskiej, po czym następowało oddanie hołdu sztandarom przez skautów, odśpiewanie amerykańskiego i polskiego hymnu przy akompaniamencie orkiestry szkoły podstawowej. Po przemówieniu wstępnym i inwokacji chóry parafialne wykonały wiązankę pieśni narodowych. Kolejne punkty programu to odczyt dotyczący Konstytucji 3 maja, deklamacja wiersza „Pogrzeb Kościuszki”, przeplatane utworami muzycznymi wykonanymi na fortepianie, klarnecie i skrzypcach. Następnie dwaj uczniowie szkoły średniej wygłosili mowy o komunizmie i o Henryku Sienkiewiczu, potem chłopcy z klasy ósmej przedstawili scenkę „Pod opieką Maryi”, a dziewczęta z chóru św. Teresy wykonały śpiewy i tańce. Na koniec Kółko Dramatyczne wystawiło jednoaktową komedię.

Parady z okazji uchwalenia Konstytucji 3 maja, które odbywają się w śródmieściu Chicago, zapoczątkowane były na Trójcowie i zwano je Manifestacją Kościuszkowską. Pochód podążał ulicą Division z kościoła pw. Świętej Trójcy do Humbold Park, gdzie stał pomnik gen. Tadeusza Kościuszki. W 1921 roku pochód odbył się 29 maja, parafia Świętej Trójcy stanowiła dziewiątą dywizję marszu, w jej skład wchodziły następujące grupy: księża, połączone towarzystwa, lokalny Komitet Narodowy, Klub Obywatelski Kazimierza Pułaskiego, skauci z własną orkiestrą i orkiestra Olejniczaka. Dywizją dowodził Józef Makarski ${ }^{38}$.

37 „Odgłos Trójcowa” 12(1920), nr 2, s. 12; „Dziennik Związkowy” 2 II 1937.

38 „Odgłos Trójcowa” 12(1920), nr 2, s. 12; „Dziennik Związkowy” 2 II 1937. 


\section{OBCHÓD LISTOPADOWY}

Od początku istnienia parafii czczono pamięć powstańców listopadowych w tzw. obchodach listopadowych, po pierwszej wojnie dołączono obchody 11 listopada, świętując zawieszenie broni. Akademię okolicznościową przygotowywały połączone towarzystwa. Zwykle stałym elementem było słowo wstępne, tzw. zagajenie przewodniczącego towarzystw, następnie skauci oddawali hołd sztandarowi amerykańskiemu i polskiemu, odśpiewano również hymny obu państw. Inwokację i modlitwę prowadzili duchowni. Na przykład w 1931 roku przemówienie wygłosił Franciszek Danisch, sekretarz Polskiej Rady Opieki Społecznej, który mówił na temat obowiązków narodowych Polonii amerykańskiej. Na program artystyczny składały się wiązanki melodii polskich i pieśni żołnierskich wykonywanych przez chóry parafialne i przez solistów przy akompaniamencie fortepianu i skrzypiec. Były też występy orkiestry szkolnej i przedstawienia dzieci szkolnych. Deklamacje wierszy patriotycznych wykonywali zwykle uczniowie szkoły średniej, odczyty fragmentów patriotycznej lektury - zwykle należały do członków Towarzystwa Młodzieży św. Kazimierza oraz Towarzystwa Młodzieży Imienia Jezus. Nie zabrakło tańców ludowych, które wykonywały członkinie towarzystw: Imienia Maryi, św. Tereni i Dzieci Maryi. Kółko Literackie odgrywało komedię, a czasami poważniejsze sztuki. Na zakończenie śpiewano „Boże coś Polskę”. W obchodach uczestniczyli weterani z I wojny światowej i zaproszeni goście, np. konsul Rzeczypospolitej Polskiej w Chicago. Przy okazji obchodów zbierano datki na cele narodowe $\mathrm{e}^{39}$.

\section{DZIAŁALNOŚĆ CHARYTATYWNA}

Działalność charytatywną parafii koordynowało Towarzystwo Dobroczynne, które we współpracy z towarzystwami żeńskimi przeprowadzało kwesty na cele dobroczynne, tzw. połowy. Główną kwestę przeprowadzano podczas świąt wielkanocnych. W celu gromadzenia funduszy na działalność charytatywną poszczególne towarzystwa organizowały losowanie wartościowych przedmiotów, tzw. wygrywki. Niektóre towarzystwa wypracowywały środki na działalność charytatywną przez organizowanie koncertów, przedstawień i balów dobroczynnych.

39 „Odgłos Trójcowa” 30(1938), nr 12, s. 18; „Dziennik Związkowy” 20 XI 1936. 


\section{IMPREZY INDYWIDUALNE}

Oprócz opisanych wcześniej celebracji organizowanych wspólnie przez organizacje działające pod zarządem Połączonych Towarzystw Parafii Świętej Trójcy, poszczególne towarzystwa organizowały własne imprezy na mniejszą skalę, pozostając $\mathrm{w}$ zgodzie z parafialnym kalendarzem wydarzeń. Nie wszystkie towarzystwa miały taką samą dynamikę działania, niektóre organizowały jedynie wewnętrzne posiedzenia i opłacały składki członkowskie. Najbardziej żywotnie towarzystwa organizowały imprezy dla całej parafii: sztuki teatralne, koncerty, bale, zabawy, majówki, „wieczorki rozmaitości” i inne. Dynamicznie działające towarzystwa obchodziły też bardzo uroczyście swoje doroczne wieczory instalacyjne, organizowały własne pikniki i wycieczki.

\section{BIBLIOGRAFIA}

Dzieje Parafii Świętej Trójcy 1873-1898. Na pamiątkę 25-letniego jubileuszu założenia parafii św. Trójcy (1898), oprac. A. Małłek i in., Chicago [1898].

Encyklopedia polskiej emigracji i Polonii, red. K. Dopierała, t. I-V, Toruń: Oficyna Wydawnicza Kucharski 2003-2005.

Kantowicz E.R., Polish-American Politics in Chicago, 1888-1940, Chicago: The University of Chicago Press 1975.

LeŚ B., Kościół w procesie asymilacji Polonii amerykańskiej: przemiany funkcji polonijnych instytucji i organizacji religijnych w środowisku Polonii chicagowskiej, Wrocław: Zakład Narodowy im. Ossolińskich. PAN Wydawnictwo 1981.

Pamiątka złotego jubileuszu kapłaństwa wielebnego księdza Kazimierza S. Sztuczki C.S.C., proboszcza Parafii Świętej Trójcy w Chicago [...], Chicago [1941].

Pamiętnik parafii Świętej Trójcy w Chicago 1893-1918. Z okazji 25 rocznicy otwarcia kościoła przez J.E. Ks. Kard. F. Satolliego, delegata papieskiego, Chicago [1918].

Pamiętnik z okazji czterdziestolecia otwarcia kościoła w Parafii św. Trójcy, czerwiec 1933, Chicago, Illinois, 1933.

Potaczala G., Polacy na Trójcowie. Dzieje kościoła pw. Świętej Trójcy w Chicago, Poznań: Agape 2007.

„Odgłos Trójcowa” - czasopismo miesięczne poświęcone sprawom parafii Świętej Trójcy 1909-1938.

„Dziennik Związkowy” 1929, 1931, 1937. 


\title{
ZORGANIZOWANE FORMY AKTYWNOŚCI RELIGIJNEJ I SPOŁECZNEJ POLSKICH EMIGRANTÓW \\ PRZY PARAFII PW. ŚWIĘTEJ TRÓJCY W CHICAGO \\ W LATACH DWUDZIESTYCH I TRZYDZIESTYCH XX WIEKU
}

\begin{abstract}
Streszczenie
Kościół Świętej Trójcy w Chicago zbudowano w 1873 roku. Po dwudziestu latach została utworzona parafia, gdzie duszpasterzami byli księża ze Zgromadzenia Krzyża Świętego. Najbardziej dynamicznie parafia działała w pierwszej połowie XX wieku. W latach 20. i 30. w parafii istniało ponad 50 towarzystw parafialnych, które prowadziły działalność zarówno religijną, jak i kulturalną oraz społeczną. Towarzystwa posiadały uporządkowane wewnętrzne struktury i podlegały nadrzędnej parafialnej organizacji, która koordynowała wszelkie wydarzenia parafialne. Towarzystwa wspólnie urządzały pikniki parafialne, bazary, bankiety itp., wspólnie przystępowały do spowiedzi i komunii św. Organizowanie obchodów narodowych i działalność charytatywna podlegały również odgórnemu zarządzaniu. Podstawowym źródłem, z którego czerpano informacje, był biuletyn parafialny, wydawany raz w miesiącu.
\end{abstract}

Słowa kluczowe: polscy emigranci; towarzystwa parafialne; rocznice narodowe; parafie polonijne

\section{ORGANIZED FORMS OF RELIGIOUS AND SOCIAL ACTIVITY OF POLISH EMIGRANTS IN CHICAGO'S HOLY TRINITY PARISH IN THE 1920S AND 1930S}

\section{S u m m a r y}

The Holy Trinity Church in Chicago was built in 1873. Twenty years later, a parish was established where priests from the Congregation of the Holy Cross ministered. The parish was the most dynamically active in the first half of the $20^{\text {th }}$ century. In the $1920 \mathrm{~s}$ and 1930s, there were over 50 parish societies in the parish, which carried out religious, cultural and social activities. The societies operated in an orderly, structured way, and reported to a superior parish organization which coordinated all parish events. The societies jointly participated in the sacraments of Reconciliation and the Holy Eucharist, and organized parish picnics, bazaars, banquets, etc. The organization of national celebrations and charity activities were also subject to top-down management. The basic source of information was the parish bulletin, issued once a month.

Key words: Polish emigrants; parish societies; national anniversaries; Polish parishes 